\title{
RELATIONSHIP BETWEEN THE ROLE OF FAMILIES IN DIET SUPERVISION AND THE LEVEL OF COMPLIANCE OF DIET MANAGEMENT AMONG TYPE 2 DIABETES MELLITUS PATIENTS IN KEBONSARI VILLAGE, CANDI SUB-DISTRICT, SIDOARJO DISTRICT
}

\author{
Meli Diana ${ }^{1 *}$ \\ ${ }^{1}$ Kerta Cendekia Nursing Academy, Sidoarjo \\ *Correspondence: \\ Meli Diana \\ Email: melly.mellon@yahoo.com
}

\begin{abstract}
Background: The Indonesia Sehat Program is a program to improve the quality of life of the Indonesian people. The target of this program is to improve the health and nutritional status of the community through health and community empowerment efforts supported by financial protection and equitable distribution of health services. The latest estimate of the International Diabetes Federation, there are 382 million people living with Diabetes in the world in 2013. By 2035 this number is expected to increase to 592 million people.

Objectives: This study aimed to determine the relationship between the role of families in diet monitoring with the level of compliance with Type II Diabetes Mellitus patients in carrying out the Diabetes Mellitus diet at Kebonsari Candi Sidoarjo.

Method: This study used correlational design with a sample of 25 people. Samples were obtained using total sampling method. The instrument used to obtain data in this study is a questionnaire. The data obtained were then analyzed by using the Spearman test with $\mathrm{p} \leq$ 0,01 .

Results: Families who play an active role in the supervision of diabetic patients with diabetes mellitus are related to the level of patient compliance in the obedient category of $44 \%$. Based on the Spearman Rank test with $\mathrm{p}<0.01$, the correlation level is 0.600 . It can be concluded that there is a relationship between the role of families in diet monitoring and the level of adherence to type 2 diabetes mellitus patients in carrying out a diabetes mellitus diet has a strong level of correlation.

Conclusion: Families are required to play an active role in supervising diabetics in carrying out the diabetes mellitus diet so that it can prevent complications of the disease and the quality of life of the sufferer.
\end{abstract}

Key words: The Role of Families, Diet Compliance, Type 2 Diabetes Mellitus

\section{INTRODUCTION}

The Indonesia Sehat Program is a program to improve the quality of life of the Indonesian people. The target of this program is to improve the health and nutritional status of the community through health and community empowerment efforts supported by financial protection and equitable distribution of health services. The implementation of a healthy paradigm is carried out through strengthening promotive, preventive and community empowerment efforts. The government's challenge in implementing a healthy Indonesia program of 2025 is still hampered by an increase in the development of noncommunicable diseases. The number of people with non-communicable diseases tends to increase in the last two decades. Diabetes mellitus is a non-communicable disease that has experienced significant development (Kemenkes RI, 2013). Household health survey (SKRT) year 2001 obtain prevalence of diabetes mellitus among people aged 25-64 years in Java and Bali by $7.5 \%$. While 
Riskesdas were conducted in 2007 and 2013 showed that the proportion of patients with diabetes mellitus in Riskesdas 2013 increased almost two-fold compared to 2007.

The goal of the management of the disease Diabetes Mellitus is a metabolic disarray recover so that everything returns to normal metabolic processes as well as prevent and slow down the appearance of complications. The main treatment of Type 2 Diabetes Mellitus focuses on the underlying problems, namely through exercise and dietary regulation. Someone who is at risk of suffering from Diabetes Mellitus is expected to reduce these risks, namely by encouraging patients to do physical activities and teach how to choose meals that can lose weight, or at least can prevent weight gain. For diabetics who need insulin, diet should be prepared not only based on the amount of carbohydrate needs in food, but also must be based on the type of insulin used. Meal time and when administering insulin must be applied discipline every day so that blood sugar can be controlled effectively (Arisman, 2008).

Constraints of type 2 diabetes mellitus patients in carrying out diet management, among others, due to the saturation of patients in carrying out diet therapy that must last long even for life and lack of family support in carrying out diet therapy. Many people with diabetes mellitus experience complications of illness caused by non-compliance in carrying out their diet therapy. Frequent complications include gangrene, diabetic ketoacidosis, and nephrotic disease diabetes mellitus. To overcome the complications caused by noncompliance in carrying out diet therapy, it is necessary to have support from the family in the implementation of diet therapy for people with diabetes mellitus. The role of the family is very important because one of the family functions according to Friedman (1998) quoted in the KEMEMKES (2013) is that the family has a function of health care or maintenance for family members who are sick. Family functions in this case, among others, as decision makers for appropriate health measures, recognizing the health problems of each family member, and providing care for sick family members.

\section{METHODS}

Study Design

The study used a correlational study design with cross-sectional method.

Setting

This research was conducted in Kebonsari Village, Candi Sub-District, Sidoarjo District from March 20, 2017 until April 14, 2017.

\section{Research Subject}

The population in this study were all of type 2 diabetes mellitus patients in the Kebonsari Village. The sampling technique was total sampling. The sample consisted of 25 people with type 2 diabetes mellitus.

\section{Instrument}

This research used closed-ended questionnaires for each variable. Variable in this research is the role of families in diet supervision and the level of compliance of diet management. The questionnaire using a guttman's scale where each questionnaire on each variable consists of ten statements.

\section{Data Analysis}

In this study, researcher analyzed using the Spearman Rank test with $p \leq 0,01$.

\section{RESULTS}

Relationship Between the Role of Families in Diet Supervision and the Level of Compliance of Diet Management among Type 2 Diabetes Mellitus Patients in Kebonsari Village, Candi Sub-District, Sidoarjo District

The results of this study showed that families actively participate in monitoring patients with diabetes mellitus diet associated with the level of patient compliance in the category of compliance, as many as $40 \%(\mathrm{r}=$ $.600, p<0.01$ ). Data of Research Results can be seen in table 1 . 
Table 1. Relationship between the role of families in diet supervision and the level of compliance of diet management among type 2 diabetes mellitus patients in Kebonsari Village, Candi Sub-District, Sidoarjo District.

\begin{tabular}{cccccccc}
\hline \multirow{2}{*}{$\begin{array}{c}\text { Role of } \\
\text { Families }\end{array}$} & \multicolumn{5}{c}{ Level of Compliance } & Spearman \\
\cline { 2 - 6 } & Adherence & \multicolumn{2}{c}{$\begin{array}{c}\text { Quite } \\
\text { Adherence }\end{array}$} & \multicolumn{2}{c}{$\begin{array}{c}\text { Poor } \\
\text { Adherence }\end{array}$} & $\begin{array}{c}\text { Test } \\
(\mathrm{p}<0.01)\end{array}$ \\
\cline { 2 - 7 } & $\Sigma$ & $\%$ & $\Sigma$ & $\%$ & $\Sigma$ & $\%$ & \\
\hline $\begin{array}{c}\text { Active } \\
\text { Quite }\end{array}$ & 4 & 44 & 1 & 12 & 4 & 44 & \\
Active & 6 & 25 & 0 & 0 & 2 & 75 & 0,600 \\
$\begin{array}{c}\text { Less } \\
\text { Active }\end{array}$ & 4 & 12 & 3 & 38 & 1 & 50 & \\
\hline
\end{tabular}

Sources: Primary Data of Questionnaire, 2017

\section{DISCUSSION}

The results of this study indicate that families play an active role in the supervision of diet diabetes mellitus have an impact on the level of compliance of patients with diabetes mellitus in the diet of diabetes mellitus in the category submissive is equal to $44 \%$, the family that plays quite an active impact on the level of patient compliance in the category of poor adherence is equal $75 \%$, while the less active role families have an impact on patient compliance in the category of poor adherence by $38 \%$. Based on the Spearman Rank test with $\mathrm{p}<0.01$, the correlation level is 0.600 . It can be concluded that the relationship between the role of the family in diet control and the level of adherence to type 2 diabetes mellitus in carrying out a diabetes mellitus diet has a strong correlation level.

Family can be a very influential factor in determining individual health beliefs and values and can also determine the treatment program they have received. Pratt in Neil (2010) has noticed that the role played by families in developing health habits and teaching of their children. The family also provides support and makes decisions regarding the care of sick family members. According to Miller and DiMatteo (2013), social support can benefit the health of patients by supporting stress, changing affective conditions, increasing self-efficacy, and influencing changes in negative health behavior. Rosland et al (Miller and DiMatteo, 2013) found that practical and emotional support received by family and friends has a positive influence on global measures of disease management in diabetic patients. In fact, the meta-analytic review of 122 empirical studies found that adherence was $27 \%$ higher if patients had the practical support available to them. In addition, research by Pereira et al (Miller and DiMatteo, 2013) showed a strong relationship between positive family dimensions and better glycemic control among diabetic patients. With regard to family cohesion, where families are described as warm, accepting, and close, the likelihood of obedience is three times higher when compared to non-cohesive families. Furthermore, family structural support is also positively associated with medication adherence. In a study by Miller and DiMatteo (2013), the likelihood of adherence to married patients was 1.27 times higher than those of unmarried patients. In addition, "living with others" had a positive effect on adult adherence $(\mathrm{r}=0.08, \mathrm{P}<0.05)$. More specifically, the effect of patient adherence and "living with others" is stronger for behavioral regimens compared to treatment regimens. In addition, in the same study, functional social support (e.g. practical and emotional support) has a stronger effect on adherence than structural social support. According to Putra (2016), family support has a strong enough relationship with eating behaviors $(\mathrm{r}=.683, \mathrm{p}<.001)$, especially in arranging a meal plan $(\mathrm{r}=.551, \mathrm{p}<.001)$, selecting a healthy diet and amount $(\mathrm{r}=.638, \mathrm{p}$ $<.001)$, recognizing the amount of calorie needs $(\mathrm{r}=.570, \mathrm{p}<.001)$, and managing dietary challenges $(\mathrm{r}=.628, \mathrm{p}<.001)$.

\section{CONCLUSION}

Based on the results of the study it can be concluded that there is a relationship between the role of families in diet supervision and the level of compliance of diet management among type 2 diabetes mellitus patients in Kebonsari Village, Candi Sub-District, Sidoarjo District with a strong correlation level.

\section{SUGGESTION}

For further research, the scope of the research should be expanded so that the number of respondents is increasing and the characteristics of the respondents are also increasingly diverse. For respondents and families, they should play an active role in finding information about diabetes mellitus and exercising control on a regular basis and improving the quality of consultation with 
health workers so that the information obtained is also of higher quality. For health institutes, it should involve families in monitoring patients so that they comply with the therapy regimens that have been provided by health workers so that the quality of their health is increasing.

\section{REFERENCES}

Almatsier, S. (2006). Higiene dan Sanitasi Pengolahan Makanan. Jakarta: PT. Gramedia Pustaka Utama.

Arisman, M. B. (2008). Obesitas. Diabetes Mellitus, dan Dislipidemia. Jakarta: EGC, 167-169.

Azwar, S. (2005). Sikap Manusia Teori dan Penerapannya. Yogyakarta: Pustaka Pelajar.

Bustan, M. N. (2007). Epidemiologi penyakit tidak menular. Jakarta: Rineka Cipta.

García-Pérez, L. E., Álvarez, M., Dilla, T., GilGuillén, V., \& Orozco-Beltrán, D. (2013). Adherence to therapies in patients with type 2 diabetes. Diabetes Therapy, 4(2), 175-194.

Kautzky-Willer, A., Harreiter, J., \& Pacini, G. (2016). Sex and gender differences in risk, pathophysiology and complications of type 2 diabetes mellitus. Endocrine reviews, 37(3), 278-316.

KEMENKES. (2013). Situasi dan analisis diabetes. Jakarta: Kementerian Kesehatan RI.

Kirkman, M. S., Briscoe, V. J., Clark, N., Florez, H., Haas, L. B., Halter, J. B., ... \& Pratley, R. E. (2012). Diabetes in older adults. Diabetes care, 35(12), 2650-2664.

Miller, T. A., \& DiMatteo, M. R. (2013). Importance of family/social support and impact on adherence to diabetic therapy. Diabetes, metabolic syndrome and obesity: targets and therapy, 6, 421 .

Nursalam. (2013). Konsep dan Penerapan Metodologi Penelitian Kesehatan. Jakarta: Rineka Cipta.

Putra, K.W.R. (2016). Self-efficacy, psychological stress, family support, and eating behavior on type 2 diabetes mellitus. Belitung Nursing Journal, 2(1), 3-7.

Siddiqui, M. A., Khan, M. F., \& Carline, T. E. (2013). Gender differences in living with diabetes mellitus. Materia socio-medica, 25(2), 140 .
Smeltzer, S. C., \& Brenda, G. Bare. (2004). Brunner and Suddarth's Textbook of Medical-Surgical Nursing. Philadelpia: Lippincott.

Slamet, S. (2007). Pedoman Diet Diabetes Melitus. Jakarta: Departemen Ilmu Peyakit Dalam FKUI.

Tjokroprawiro, A. (2004). Jenis Pola Diet Penderita Diabetes Mellitus. Jakarta: Gramedia Pustaka.

Cite This Article As: Diana, M. Relationship Between the Role of Families in Diet Supervision and the Level of Compliance of Diet Management among Type 2 Diabetes Mellitus Patients in Kebonsari Village, Candi Sub-District, Sidoarjo District. Nurse and Health: Jurnal Keperawatan 2018; 7(2): 93-96. 